Western University

Scholarship@Western

Department of English Publications

English Department

Winter 1993

\title{
Charting the Anger of Indian Women through Narayan's Savitri
}

Teresa Hubel

Huron University College, Canada, tdhubel@huron.uwo.ca

Follow this and additional works at: https://ir.lib.uwo.ca/englishpub

Part of the English Language and Literature Commons, Feminist, Gender, and Sexuality Studies Commons, and the South and Southeast Asian Languages and Societies Commons

Citation of this paper:

Hubel, Teresa, "Charting the Anger of Indian Women through Narayan's Savitri" (1993). Department of English Publications. 130.

https://ir.lib.uwo.ca/englishpub/130 


\section{CHARTING THE ANGER OF INDIAN WOMEN THROUGH NARAYAN'S SAVITRI}

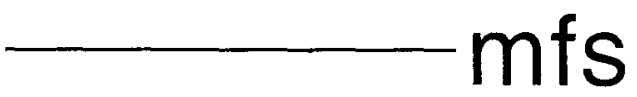

\section{Teresa Hubel}

A fiRST READ THROUGH R.K. NARAyAN'S THE DARK ROOM is apt to produce a response halfway between shock and chagrin. Since it is hardly the Narayan novel that people usually choose as an introduction to his work - the others are so much more popular and therefore available-we come to it expecting the same kind of lighthearted and gentle sketch of Malgudi that we find in his fiction generally. We expect a tone of amused tolerance. We expect what is fundamentally a conservative approach to the world of south India, an approach that views change as, to use Meenakshi Mukherjee's words, "a play of shadows, an illusion, an unreality like a bubble, which will burst sooner or later, and the normal order of the cosmos will prevail again" (155). But The Dark Room does not give us this security. Instead, it offers its readers a mixture of anger, despair, confusion, and belligerence. William Walsh is clearly disappointed with the novel when he writes,

The Dark Room is unusual in the Narayan canon in several respects. It is, for example, the closest Narayan comes anywhere to arguing a case. It shows, I think as a consequence, at certain places a wash of unabsorbed feeling. There is a touch of hysteria in the material, and the phrasing at times has a markedly antique and dated quality. (43)

My original impression of the novel was a similarly dissatisfied one. But a moment in the Nehru Memorial Museum and Library in New Delhi, where I was doing research on the pre-1947 women's move- 
ment in India, brought about a cataclysm in my appreciation of The Dark Room. That "touch of hysteria," which Walsh detects in the subject matter, and the singular bitterness so prevalent throughout the novel made perfect sense in relation to the polyphonic and increasingly strident voices that were raised in debate of the women's question in the 1930s. Suddenly, it was precisely the work's "markedly antique and dated quality" that seemed relevant.

Written in the late 1930s, when a new irascibility crept into the largely female-produced discourse on the status of women in India, The Dark Room is about a particular woman's indignation and revolt. Savitri is a Hindu wife following in the glorified footsteps of other Hindu wives, such as her namesake from the Mahabharata and Sita of the Ramayana. Although she lives up to the ideals of servitude and devotion implicit in these powerful feminine figures, Savitri of The Dark Room is betrayed by a patriarchal system that allows her hustsand the freedom of infidelity but denies her the right to economic independence. At the close of the story she finds herself trapped in a marriage that she cannot end and that she can barely alter. But Savitri does rebel, though her rebellion is enormously circumscribed by her gendered helplessness. That Narayan documents her rebellion as well as her helplessness and, significantly, refuses to close on the endnote of tranquillity and detachment that characterizes most of his novels (the two qualities that Western literary scholars like best to celebrate in his work) makes The Dark Room a radical exception.

What I am going to argue in the pages that follow is that The Dark Room not only reveals the traces of the 1930 s women's movement in India in its intersections with Indian nationalism of the time, but also that these traces ground the novel in ways that resist the discourse of timelessness that we have come to expect in Narayan's work. Understood within its historical context, this novel is a tes. tament to a particular kind of female loneliness and loss. Outside of that very timely arena, The Dark Room can look like an aberration and feel like a disappointment, though neither of these responses does justice to its powerful message. Before we can explicate that message, we need first to acknowledge and explore the political circumstances that middle and upper class Indian women confronted in the period surrounding the production of this novel.

The Indian women's movement began to adopt some new tactics in the late 1920s and throughout the thirties and forties. We hear in many of the nationalist and social reform texts written by the women of these decades an angrier and more aggressive tone and a willingness to confront certain issues that had previously been repressed or shunted aside in the interests of maintaining a united front, with the male-dominated Indian National Congress, against the 
forces of British imperialism-the British government, most British residents in India, and Christian missionary organizations. That these issues had been repressed was a consequence of the emergence of the women's movement in India as an adjunct to the anti-imperialist project.

It is a truism in histories of nationalism to describe the advent of Indian women into the political realm as precipitated by Indian men. Hence in their 1986 discussion of the nineteenth-century agitation for social reform in areas concerning women, Joanna Liddle and Rama Joshi observe that "During this time the number of men's organizations working for an improvement in women's position expanded, and some of the men encouraged their female relatives to set up corresponding women's organizations" (20). This process, that is, the introduction of women into politics through the encouragement of their men, is usually depicted as repeating itself in the early twentieth century with the rise of Mohandas K. Gandhi as a leading nationalist figure. Whereas it is generally agreed that in the previous era women took part in politics in limited numbers, they are said to have come out in droves in answer to Gandhi's call. An activist involved in the 1930s and forties agitation for women's rights and later a Minister of External Affairs under Jawaharlal Nehru, Lakshmi N. Menon asserts in a 1976 government publication that women's participation in the early nationalist movement was "practically nil" (23). It took the presence of Gandhi to change all that: "Gandhiji's message offered to the women of India an opportunity to break away from the past with all its frustrations" (26).

It is hardly surprising that historians today and one-time freedom fighters such as Menon should reconstruct the early women's movement in this fashion, since women activists during the nationalist era itself were constantly crediting Gandhi with founding the women's movement or at least with revivifying it. Hansa Mehta writes in a 1947 article about Gandhi, "From the dumb, timid and suppressed creature that she was, Gandhiji made the Indian woman into a person, self-respecting, self-confident, and more assertive of her rights and at the same time conscious of her duties" (109). This tendency among women activists in contemporary and in nationalist India to valorize Gandhi's contribution to the founding or refounding of the women's movement in the twentieth century, even over the contributions of Indian women themselves, goes some of the way towards explaining the subtle change in attitude that I have detected in the political writings of women in the thirties. Gandhi was, by the 1930s, rapidly becoming a thoroughly entrenched figure of authority for women. A reaction was therefore forming around his writings and speeches and opinions about women fueled by middle and upper class women, though a few men-the most prominent being Ja- 
waharlal Nehru-contributed to it as well. This reaction consisted of a refusal to remain silent concerning the issues that would have provoked Gandhi's disagreement, issues such as middle class women's demand for economic independence and their renunciation of the self-sacrificing feminine roles that Indian tradition had assigned to them. Furthermore, I would argue that this change in attitude about Gandhi constitutes a rebellion against the orthodoxy that he had, to some extent, come to represent. ${ }^{1}$

What gave these female activists the courage to speak out about these issues, in spite of Gandhi's opposition to them, was the support of other women. The thirties and forties saw the coming into national prominence of the All India Women's Conference (AIWC), an organization which retained strong connections to the Congress throughout the nationalist struggle but which nevertheless provided the arena for the expression of political problems related distinctly to women and for the furtherance of women's leadership. Founded in 1927, the AIWC was originally dedicated to the promotion of wornen's education. However, as Liddle and Joshi note, the female members "found that they could not discuss education without also addressing the social problems of purdah, dowry, child marriage and widow remarriage, and that these could not be separated from the political issue of India's subordination to Britain" (21). By the thirties, the AIWC had evolved into an influential political and social reform organization determined to help Indian women break away from the customs and traditions that had kept them oppressed and dependent.

Initially, the rhetoric of the women involved in the AIWC targeted inauthentic custom and corrupted tradition as the enemy. By placing emphasis on what could be construed as superficial and repairable, namely the current social situation, these women, who were also nationalists, avoided attacking an India that they were, in another sphere, dedicated to defending. This India, the one they felt needed to be protected from the insulting and intrusive attention of British imperialists, remained, for them, pure and untainted by years of foreign rule and the consequent social degeneration. Hence Kamaladevi Chattopadhyaya, identified as the secretary of the AIWC in the 1929 collection Women in Modern India: Fifteen Papers by Indian Women Writers, can differentiate between the "nightmare" (4) that India has become in the twentieth century and the "real great India" (8) which exists beneath the surface of her "misguided society" (6). It is the "real" India she is determined to resurrect in this article. She therefore constructs a magnificent India of the Vedic past, and in this India all the injustices, so prevalent in Chattopadhyaya's own time, are absent from the lives of women:

In those beautiful days of the Vedic period of India the glory of which still surrounds the country like a faint halo, women took part freely in the social 
and political life of the country.... Such social disabilities as purdah and child-marriage were entirely unknown. Women travelled about freely and had a voice in the selection of their partners in life... . Coming to their economic position, one finds that it was perfectly secure. Their rights of inheritance and succession were fully recognized, whether they were widows or daughters. ("Status of Women" 1-3)

Because of such rhapsodizing on the female freedoms of ancient India, Chattopadhyaya cannot quite account for the current state of things. She insists that the contemporary women's movement is an outgrowth of the glorious past and that "intellectually and psychologically woman in India has never lost her honoured place of old' (4), but her argument gets caught in contradictions when she tries to acknowledge the efforts of women to eliminate such social ills as purdah and child marriage. How these "evils" (10) arose out of a society that originally treated its women as equals is never explained.

The problem is that Chattopadhyaya has to perform a balancing act. On the one hand, in order to maintain her alliance with the nationalist movement, which was male-controlled and dominated by Gandhi at this time, she must refrain from criticizing Indian men and focus instead on Indian custom. Criticism of Indian patriarchy gave British imperialists ammunition in their struggle with Indian nationalists. By calling attention to the degradation of women in India and attributing that degradation to a repressive indigenous patriarchal structure and the actual conduct of Indian men, she would be concomitantly suggesting that imperialism was a necessary means of protecting Indian women from their dangerous husbands, fathers, uncles and brothers. Chattopadhyaya is thus very careful to point out that, unlike the women's movement in Europe, in India women's agitation for social reform "cannot in any sense be said to be a rebellion or a revolt against man" (5).?

But on the other hand, there is her commitment to the goals of the AIWC and to the improvement of the status of women in India. In affirming that commitment, she must admit to the existence of certain social "disabilities" among Indian women. Outlining the work of the women's movement, she refers to a vigorous propaganda campaign, which is intended to make people of all classes aware of the subjugation under which women are forced to live after marriage:

Thus the supreme overlordship of man and particularly that of the husband is strongly questioned. The women seek to have their own free choice in the selection of partners in life, the right to enter the state of motherhood, when and if they desire, to seek divorce if necessity arises. (10)

Her comments here, however, inevitably controvert her earlier statement that the Indian women's movement is by no means engaged 
in a revolt against Indian men. Clearly the above passage suggests that such a revolt is, to some extent, necessary if Indian women are to achieve their goal of equality in marriage. Hence although Chattopadhyaya seems determined to identify corrupt Indian custom as the enemy, she must also locate that custom in the practices of such men as Indian husbands. The man-woman antagonism that she is intent on denying creeps into her rhetoric anyway.

In the first few years after the inception of the AIWC, the female members tended to align themselves publicly with Gandhi's approach to the women's question. We hear particularly Hindu women activists frequently citing as models the same female figures from ancient Sanskrit literature that Gandhi revered. Chattopadhyaya does this in her reconstruction of the Vedic past:

All those who are held so reverentially as great ideals, Sita, Savitri, Draupadi, were those who enjoyed a high degree of freedom and asserted their individuality. They were by no means content to be mere shadows of their husbands, as the general belief seems to be now. ("Status of Women"2)

Chattopadhyaya's evocation of these three female paragons is, at this stage in her career, substantially in accordance with Gandhi's construction of ideal Indian womanhood. Gandhi called up these heroines constantly in his speeches and writing, comparing them to the women of his time in order to posit an ideal for which they could strive. For example, in 1918, while speaking to the members of Bhagini Samaj, a women's welfare organization, he stated that the regeneration of the Indian woman must inevitably involve removing the "blemishes" that had come to be associated with her character because of such social evils as child marriage and the restrictions placed on widows. And he added, "In my humble opinion in order to make the attempt we will have to produce women, pure, firm and self-controlled as Sita, Damayanti and Draupadi" (Speeches 106). Additionally, in a 1927 article on the uselessness of purdah, he speaks of Sita's "defiant" chastity and Draupadi's "robust independence" (Writings 235), and earlier in 1926, while defending the ideal of "pure widowhood," he uses Savitri, Sita, and Damayanti, all Hindu literary characters renowned for their devoted wifehood, as models for Indian widows, though none of these figures is represented as a widow: "Savitri entered into a spiritual union, so did Sita and Damayanti. We cannot even imagine such women, should they become widows, ever marrying again" (Works 36). It is significant that Gandhi's reclamation of these heroines tends to underscore their chastity, their enormous capacity for suffering, and their devotion to their husbands. Although Chattopadhyaya tries to shift the emphasis to their individuality and liberty in her description of 
Vedic India, Gandhi's control of this discourse was such that these names had, by 1929, become synonymous with self-sacrifice. And so pronounced was his influence on this discourse and the women nationalists who used it that Sarojini Naidu, in her 1925 presidential address to the Congress, would invoke these same figures as her model, without once mentioning the present conditions under which women in India lived and which women activists were determined to ameliorate:

I trust, that to the fulfillment of the lofty task you have allotted me, even I might bring some glowing ember of the immortal faith that illumined the vigil of Sita in her forest exile, and bore the feet of Savitri undaunted to the very citadels of Death. (Ghose 187)

When Chattopadhyaya therefore conjures up Sita, Savitri, and Draupadi, she is tapping into a nationalist tradition about Hindu women that had become firmly established by the time she wrote her paper for Women in Modern India.

But by the 1930s Chattopadhyaya and other women activists had found their own voices and their own leadership. And what they had to say was no longer always in keeping with Gandhi's perspective. Nowhere is this more apparent than in Chattopadhyaya's works. Not only does her writing cease to reflect the florid and sentimental style that Gandhi used whenever he spoke or wrote about India's women, it gives expression to a new indignation: we might even call it rage. Chattopadhyaya was throughout the thirties involved in a fierce campaign to raise public awareness about the Sarda Act. This act, which was aimed at preventing the marriage of girls under 14 and boys under 18, was actually passed in 1929 , but it threatened to remain ineffective because it lacked state enforcement and public backing. Indeed, opposition from the orthodox elements of both the Hindu and Muslim populations was virulent. But the response from the activists of the Women's Conference was equally ferocious. In a book entitled The Awakening of Indian Women. which was published in 1939, Chattopadhyaya denounces the tendency of Indian families to arrange early marriages for their daughters in defiance of the law. Over half of the girls in India, she states, are still married under the age of 15 . She goes on to say angrily,

But these figures hardly indicate the enormity of the damage. These reports pass silently over hundreds and thousands of young blossoming girls, wrecked for life physically and psychologically by forced premature motherhood. By all moral codes, it is rape but our social conscience is hard bound by dead old usages.... So the murders and rape go on, while we sit and gloat over the past glories of dead and gone Seetas and Savitris! (16)

This repudiation of Hinduism's pure and selfless heroines, a repudiation conducted in the name of the thousands of girls in modern 
India who suffer because of such images of women, stands in powerful contrast to Chattopadhyaya's earlier evocation of Sita and Savitri. Two different political programs are being rejected here. First, by calling the act of sexual intercourse with girl brides "murder" and "rape," which implicitly posits male murderers and rapists, she is refusing to sidestep the issue of men's personal oppression of women. Although she continues to cite Indian custom as the enemy, the suggestion that Indian men are responsible as well is everywhere apparent. Second. Chattopadhyaya is giving up her allegiance to the Hindu past and to the reconstructed Vedic tradition that Gandhi held so dear. Uma Chakravarti observes in a recent article about the nationalist reconstitution of ancient Hindu history, that this perception of the past as a lost glory is burdensome, particularly for women: "It has led to a narrow and limiting circle in which the image of Indian womanhood has become both a shackle and a rhetorical device that nevertheless functions as a historical truth" (28). That this feminine ideal was more imprisoning than empowering and that this "truth" was one that needed to be gainsaid is, I think, Chattopadhyaya's point in the passage I quoted above.

Nevertheless, Chattopadhyaya does not here, or anywhere else that I can find, openly question or challenge Gandhi's ideas about women. None of the women activists did. Although many of them in the thirties were prepared to take a stance in contravention to Gandhi's expressed views on the subject, they would not acknowledge that this was, in fact, what they were doing. Their rebellion goes unconfessed. The issue of women's economic dependence illustrates this elision.

Gandhi was very much opposed, throughout his political life, to the possibility of Indian women working. He believed that men and wornen were designed to conduct their lives in separate spheres, the women's sphere being obviously that of the home. On the question of women's education, he was therefore committed to the notion that the sexes needed to learn different things. He told an audience of women in 1918 ,

Man is supreme in the outward activities of a married pair and, therefore, it is in the fitness of things that he should have a greater knowledge thereof. On the other hand, home life is entirely the sphere of woman and, therefore, in domestic affairs, in the upbringing and education of children women ought to have more knowledge. (Speeches 109)

A few sentences later, he emphatically asserts, ". . I do not believe in women working for a living or undertaking a commercial enterprise" (Speeches 109). He repeats much the same argument in the journal Harijan in February, 1940, which suggests that his position on this subject did not undergo any change at all in the course of those twenty or so years when women were becoming increasingly politicized. 
Many people supported Gandhi in this contention, some of whom were women. ${ }^{3}$ But beginning in the thirties, the women activists of the Women's Conference and of other such organizations were adamant in their disagreement, though they refrained from actually citing Gandhi, unquestionably the most influential man in the country, as the source of their dispute. A fascinating book entitled Our Cause: A Symposium by Indian Women, which was published in 1936, is a record of their disillusionment with Gandhi's ideas and with the nationalists' efforts at female emancipation. It is severe in its condemnation of certain Indian customs and beliefs, and, implicitly, of the men who put them into practice. Most of the women who wrote for Our Cause do not seem willing to temper their repudiation of India's patriarchy with praise for the female figures from India's glorious past.

In this text marriage in particular comes under attack. It is constructed by different writers not as spiritual union, as Gandhi liked to describe it, but as a system of slavery, in which the wife is deprived forever of her liberty. The editor of Our Cause, Shyam Kumari Nehru, writes,

It is a cunning device to keep woman economically dependent on man, chained within the four walls of the zenana, confined to the performing of household duties alone. Usually marriage is thrust on her much before she can think for herself, and the tie is indissoluable. (xii)

G. J. Bahadurji is even more contemptuous of the Indian marriage in her contribution to the book, "Women and Political Struggle." For her, marriage, as it existed in the thirties, unequivocally constitutes "bondage," for it makes women dependent on men even in their political decisions. The British government's India Act of 1935 widened the franchise for women by giving those women who were married to or widowed by a male property owner the right to vote. But Bahadurji rejects this right, saying "the new womanhood of India might quite conceivably elect to forgo such rights rather than accept such bondage as a sort of condition precedent to political recognition" (327). According to Bahadurji, marriage not only transforms a woman into either a "dressed up doll" or a "beast of burden" but its corollary, motherhood, ensures her lifelong slavery: "her creations [become] the bonds that tie her to the yoke of family life, which, once entered, leaves no room for self-expression, or selfrealisation" (324). At a time in India when marriage and motherhood were both considered sacrosanct-motherhood, in fact, became a national beatitude once India was constructed as the motherlandthese are undoubtedly insurgent words.

What Nehru, Bahadurji, and other women writers call for in Our Cause, namely, economic independence for women and the right to choose or not choose motherhood, later became a rallying cry 
for the women of the AIWC. By 1945, when Hansa Mehta gave her rousing presidential address to the Conference, there was no longer any suggestion that these women shared Gandhi's convictions about the future of Indian womanhood. Mehta argues that the Indian woman, for her own personal evolution, requires access to the same educational system available to man: "Woman shall have facilities for training for any profession or occupation that she may choose to follow" (7). Furthermore, she insists that she has a right to work and a right to "receive the same payment as man for the same amount of work" (9). Even the housewife, she asserts, is entitled to a portion of her husband's income. In short, the Indian woman "should have no feeling of dependence on man" (10). Although Mehta and other women activists continued to speak about Gandhi and his contribution to the women's movement with enormous respect, the days of their assimilating his beliefs concerning their lives and their futures were over. After independence, Mehta would even go so far as to say that "to learn to think for oneself is what we need today instead of taking shelter behind Gandhiji's words in everything we do. We have got over what Manu said; we shall have to get over what Gandhiji said" (191). Manu was a patriarch of the first or second century who wrote a law code notorious for its misogyny.

A similar kind of female rebellion against an established authority is the subject of Narayan's The Dark Room. It is significant that he chooses to center Savitri's revolt on those two issues from the 1930s women's movement that inspired such anger and determination in women activists of the time, specifically the demand of middle class women for work outside the home and their efforts to move beyond the discourse of the selfless heroine. Like these women, Savitri is concerned with her economic dependence, and in her quest for self reliance, she is forced to come to terms with the legacy of the earlier Savitri. Narayan's decision to ground his novel so thoroughly in the female politics of the time suggests that Savitri's story can be read as his attempt to comprehend the emotional and political reality of women's lives in the thirties. ${ }^{4}$

At the opening of the novel Savitri is unaware that it is her economic dependence on her husband Ramani that ensures her impotence in other areas of her life. When she is unable to keep her son Babu home from school, because Ramani does not believe he is ill, she assumes that her powerlessness is the result of a previous passivity: "she felt she ought to have asserted herself a little more at the beginning of her married life and then all would have been well" (6). She believes that she is lacking some wifely trait, the absence of which explains her enormously inequitable 
relationship with Ramani. Hence it is not the role of Indian wife that she questions so much as her particular performance of it. She turns to other wives for advice, looking for models of the kind of wifely behavior that will allow her more power in her marriage.

Her friend Gangu is, in her mind, an example of a woman who has "absolutely tethered up her poor man" (6), and the novel seems to share Savitri's mixed feelings about this character and her female assertiveness. Gangu is represented as a woman whose ambitions are silly: she wants to be a film star, a professional musician, the Malgudi delegate to the All India Women's Conference, and a Congress leader, though she does not appear to have the talent to fill any of these positions. But Gangu also has the freedom and the courage that Savitri clearly lacks. The novel seems to be telling us that Savitri should be more like Gangu at the same time that it represents Gangu as a poor model of womanhood.

The contradiction arises again when the character of Ponni is introduced. A woman of a low caste and class, Ponni is the wife of the man who rescues Savitri during her suicide attempt. Like Gangu, Ponni is aggressive, and especially so in her relationship with her husband Mari. When Savitri confesses to Ponni that she has left her home because of her husband's sexual infidelity, Ponni offers the following advice: "Sister, remember this. Keep the men under the rod, and they will be all right. Show them that you care for them and they will tie you up and treat you like a dog" (136). Once Mari is out of earshot, Ponni adds that he is a "splendid boy," except when he gets drunk, at which time "he will come home and try to break all the pots and beat me" (136). Her solution to this problem is to trip him, sit on his back, and refuse to get off until he falls asleep. With such a technique at her disposal, Ponni is confident that she is safe. She tells Savitri, "I can't believe any husband is unmanageable in this universe ..." (137). Ponni loves Mari but is prevented by her fear of him from showing it. Moreover, her verbal and physical tyranny over Mari leaves him resentful and bitter, and we are, in part, encouraged to sympathize with his inability to stand up to her. The narrator explores Mari's feelings after he has been charged with the responsibility of finding Savitri a job:

He felt angry at this wife for her fussing. Why couldn't she leave the woman alone? This was what came of allowing too much liberty to women; they ought to be kept under proper control and then all would be well. He felt irritated with himself at his own helplessness before his wife. (161)

Theirs is clearly not an ideal marriage, since the physical inequality is simply tilted in a less traditional direction. Nevertheless, the novel does posit this as the best of all the marriages depicted because 
it is founded on love. Society's expectations about the conduct of married men and women is responsible for distorting Ponni's and Mari's love for one another.

Janamma is the novel's model of a conventional Hindu wife. Before she learns about Ramani's affair with Shanta Bai, Savitri sees Janamma as a wife worthy of imitation. During her first retreat into the dark room-after Savitri finds herself unable to stop Ramani from beating Babu-it is Janamma who comes to the dark room to comfort her. Janamma claims never to have opposed her husband and recommends that Savitri similarly capitulate. Her justification for such behavior is double-edged. She believes that men are better trainers of children and that women are required by tradition to submit. To demonstrate the validity of her argument, she recounts stories about other patient wives:

her own grandmother who slaved cheerfully for her husband who had three concubines at home; her aunt who was beaten every day by her husband and had never uttered a word of protest for fifty years; another friend of her mother's who was prepared to jump into a well if her husband so directed her; and so on, till Savitri gradually began to feel very foolish at the thought of her own resentment, which now seemed very insignificant. (60)

This burden of history, which inspires Savitri to live up to the ideals implicit in her name, initially provides her with enough meaning that she is able to stay willingly with a husband who is domineering and occasionally abusive.

Although the novel gives us a variety of wifely role models, none of them in the end proves to be sufficient, for none can grant Savitri the equality she needs to be happy. Gangu's example offers her freedom at the expense of social acceptance; Ponni shows her how to achieve tyrannical power in her marriage; and while Janamma demonstrates the qualities of the traditional Hindu wife, Savitri finds that she cannot patiently acquiesce in the face of Ramani's infidelity. As the novel progresses, it becomes clear that Savitri's uncertainty, Gangu's silliness, Ponni's severity, and Janamma's subservience are all problems. For they are all products of a patriarchy that forces women into extremes of domination, submission, or isolation. Furthermore, that the institution of marriage in India does not make Indian women happy seems to be one of the underlying assumptions in The Dark Room. On this issue, then, Narayan's novel corresponds to the statements made by the women activists of the thirties and forties. Like Nehru and Bahadurji, Narayan constructs marriage as a form of slavery in which women are kept in bondage for life. But Narayan's vivid recreation of Savitri's subjection, which is so intolerable that it takes her to the point of suicide, and his refusal to attenuate her oppression by positing a way out makes his construc- 
tion of this celebrated Indian institution even darker. The Dark Room can, I think, be interpreted as Narayan's repudiation of Indian marriage just as The English Teacher is usually read as his tribute to it.

Once she realizes that it is not her own failings but the very condition of Hindu wifehood that is making her miserable, Savitri can diagnose her situation more accurately. When she leaves home, casting off all her diamonds and gold, including those given to her by her father, saying, "They are also a man's gift" (114), she begins to chart the depths of her helplessness as an Indian woman. Her recognition that every position available to her-as Ramani's wife, or Babu's mother, or her father's daughter-leads her to despair. "No one who could not live by herself should be allowed to exist," she concludes (119).

Savitri's subsequent search for some work that will allow her to support herself is partially successful; that is, she does find a job cleaning a temple. But the fear that overwhelms her during her first night without her family demonstrates both to her and to the reader that her economic dependence has been internalized. She learns the sad truth that marriage has made her impotent, incapable of freedom, and entirely unequal to the task of living alone. All Indian women are included in Savitri's condemnation of herself:

"What despicable creations of God are we that we can't exist without a support. I am like a bamboo pole which cannot stand without a wall to support it" ... "This is defeat. I accept it. I am no good for this fight. I am a bamboo pole." (189-190)

That women in The Dark Room need work outside the home is evident not only from Savitri's situation but from Shanta Bai's and from the fact that some 200 women applicants apply for the job at the Engladia Insurance Company, which Ramani eventually gives to Shanta Bai (63). Narayan is therefore in agreement with the AIWC when he depicts his female characters, and particularly his protagonist, as desperate for work. Where he differs from the activists, however, is in his questioning of women's readiness for economic independence. Savitri's inequitable relationship with Ramani is such that she clearly needs work in order to escape the subjugation of her marriage, but neither she nor, for that matter, Shanta Bai are emotionally prepared for independence. The problem is that both of these women carry their oppression inside them and, consequently, their access to work does not give either of them self-reliance. What Narayan seems to be suggesting is that the generation of women already married in the thirties is something of a lost cause because these women have been so suppressed that they are completely incapable of living outside the parameters of their own servitude. 
The only hope the novel holds out is for the next generation, Savitri's daughters, Sumati and Kamala. It is they and not Savitri who might circumvent the social codes that dictate their gendered powerlessness. Savitri's experience of Ramani's infidelity and her own aborted attempt at escape makes her determined to see them independent: "Sumati and Kamala must study up to the B.A. and not depend for their salvation on marriage" (120). For Narayan, the emancipation of the Indian woman must be deferred.

In the meantime, however, there are rebellions to be made. Savitri's resistance to her husband is not without its successes; she does manage to cast off one of her outdated allegiances. Like Kamaladevi Chattopadhyaya, Savitri in The Dark Room rejects the heroines of Hindu literature whom she is expected to emulate. Savitri of the Mahabharata confronts Yama, the god of death, and wins her husband Satyavan back from the grave. But in the course of her story, Narayan's Savitri frees herself from this earlier Savitri, this representation of wifely devotion and selflessness. We can chart the transformation of her ideals through an incident repeated in the opering and closing chapters of the novel.

In the first rendition, Ramani arrives home in the evening after work and, to everyone's relief, he is in a good mood. As an expression of his cheerfulness, he amuses his wife by asking her if she has eaten and then rewards her with praise and the freedom to respond playfully when he learns that she has waited for him:

"What a dutiful wife! Would rather starve than precede her husband. You are really like some of the women in our ancient books."

"And you?" Savitri asked. She could take any liberties with him now. She could say anything. She could be recklessly happy and free. (14)

This lighthearted banter is clearly one of the touchstones of their marriage. At this point Savitri is obviously pleased when her husband compares her to the wives memorialized in Hindu literature, and she gratefully accepts his offer to be playful and romantic. But a different Savitri exists at the end of the novel, and this Savitri is not quite able to play the game anymore. When Ramani initiates the banter with the opening line, "What a dutiful wife you are!" (207), Savitri's responses are labored and difficult. Her smile is forced, her jokes are "miserable," and she finds herself thinking, "A part of me is dead" (208). Though Ramani wants to continue the jesting after the meal, Savitri refuses because she is tired.

At the close of her story Savitri is no longer Ramani's plaything nor is she his "dutiful wife." Although she performs the tasks ex. pected of her as a married Indian woman, she has lost the inspiration that gave those tasks meaning. Her recognition that Ramani is no Satyavan has produced the accompanying knowledge that she is 
therefore not required to be Savitri. Ramani's life and death are his own affair. Her tragedy is, of course, that this recognition does not bring her freedom. Although her marriage has become a sham according to the same standards that dictated her Savitri-like behavior, she does not have the courage to renounce it. And we cannot blame her.

As so many critics have observed, Narayan's novels are fundamentally about the re-establishment of order; they are about acquiescence and endurance and willing submission to the greater forces that orchestrate people's lives. These themes are what most Western and Indian scholars tend to admire in Narayan's work, for they seem to point to some essential "Indianness." (That such a notion of "Indianness" has been constructed out of imperialist and nationalist discourses usually goes unmentioned.) But if this is "Indianness," then wha: we find in The Dark Room is unIndian. Savitri is not acquiescent in the end, she is defeated; she does not willingly submit to greater forces but to an oppressive social structure; and if she endures, this is not so much from choice but because she has tried to kill herself and has been prevented from doing so. Narayan's last image of Savitri shows her lonely and isolated, feeling worthless and impotent. The Dark Room therefore seems far more a call for change than serve as a panegyric to cosmic harmony.

Narayan's Savitri is precisely the kind of woman for whom the activists of the AIWC were hoping to make change, an elite Hindu woman trapped and enslaved by entrenched upper caste customs. Although the AIWC did occasionally attempt to politicize women from the lower castes and to include in their movement women from other religious traditions, the Hindu upper caste woman remained the focus of their efforts-perhaps because most of the prominent women of the AIWC were members of this particular class and religion. In the writings of the women activists of the thirties and in Narayan's The Dark Room the voices of Muslim, Christian, Parsee, Anglo-Indian, Jewish, untouchable or lower caste women are either absent or decentralized. What about their anger? One essay in Our Cause, "Indian Muslim Women-A Perspective" by Sakinatul Fatima Wazir Hasan, testifies to the anger of at least one Muslim woman. Hasan writes, "There is no other Muslim country in the world where in social matters like the purdah, marriage, and status of women generally, so much dullwitted reaction prevails as in India" (24). And Iqbalunnisa Hussain's 1944 novel Purdah and Polygamy: Life in an Indian Muslim Household angrily delineates a patriarchal structure that subjugates Muslim women as fiercely as its Hindu counterpart suppresses the talents and aspirations of Hindu women. In The Dark Room the low caste woman Ponni stands in for an entire class of 
Indian women who did not speak in the women's movement's elite narratives. The female voices of colonial India's minorities are generally hard to locate and even harder to hear. But they exist along the edges of an already marginalized discourse-the discourse produced by and about upper caste Hindu women. I invoke these female voices-all of them, the Hindu and the minority-now, at the end of this paper, because of their circular interconnectedness. To make matters even more complicated, I posit myself as interested observer and literary critic, me-a white Canadian woman writing fifty years in the future of the Indian women, fictional and otherwise, whose names appear in these pages. We are all riding on one another's backs.

\section{NOTES}

${ }^{1}$ While it is true that Gandhi did share certain beliefs with the orthodox Hindu population in pre-independence India, it would hardly be just to dismiss him as merely orthodox. Like Partha Chatterjee in Nationalist Thought and the Colonial World, I too am convinced that Gandhi offered India a potentially radical alternative to Western industrialism. Moreover, many of the women activists whose names appear in these pages also believed that Gandhi's program for the future of India in general and for Indian women in particular contained the possibility of great change. Gandhi did, however, have a few blind spots, ideas which he presented as revolutionary but which, in fact, were rooted in conservative modes of thought. His attitude to women, while extremely respectful, was at times condescending. And he seemed unable to envision an Indian woman who was radically different from the way Indian traditions had for centuries constructed her.

${ }^{2}$ This has become something of a refrain in Indian women's history. Aparna Basu, for example, repeats much the same thing in her 1976 article erititled, "The Role of Women in the Indian Struggle for Freedom," as do numerous other Indian women who attempt to reconstruct the nationalist past.

${ }^{3}$ Writing by women that advocated Gandhi's conviction that Indian women were primarily answerable to the dictates of the home was common in pre-Independence India. Radhika Lal Tarafdar, for example, published a pamphiet herself in 1936 entitled Womanhood in Hindu Society Ancient and Modern in which she argues that, though women should be permitted a "liberal and higher education," her chief duty was to her family and house. She adds, "When a woman forsakes her home for hard manly work she forsakes her highest opportunity in life" (47-48). The women activists who took an alternative stance therefore found themselves not only in opposition to Gandhi and many male nationalists but to many women nationalists as well.

${ }^{4}$ it seems appropriate at this point to acknowlege the dislocations inherent in what I'm trying to do here-namely, chart the anger of the Indian women of the thirties through not only the political writing of certain elite Hindu women but also through the fictional work of a canonical male writer. My reasons for choosing Narayan's novel as the focus for my theories about female anger in colonial India rather than a novel by an Indian woman need to be clarified.

In my own research I have come across few Indian novels in English written by women prior to independence in 1947. Those that exist, however, are fascinating and frequently rebellious constructions of domestic reality in india, and I'm thinking 
here specifically of Swarnakumari Devi Ghosal's English fiction (a collection of short stories [1919] and two novels-An Unfinished Song [1913] and The Fatal Garland [1915]) and labalunnisa Hussain's marvellous novel Purdah and Polygamy: Life in an indian Muslim Household (1944). While there is certainly anger towards an androcentrically structured society that circumscribes women's freedom expressed in all of these works-its expression is more explicit in Hussain's than in Swarnakumari Devi's writing - neither of these two writers produced their fiction in the 1930s, a period which, as I have argued in this paper, saw an important transformation in the way that women activists approached their own emancipation. Swarnakumari Devi, a Bengali Hindu, published her English fiction before 1920, when the nationalist movement went very much hand in hand with agitation for women's reform in India. We do not see in her writing the kind of open revolt that Savitri unleashes in The Dark Room, partially reflecting, I argue, the mood apparent in the writing by women activists in the twenties and thirties. Hussain's novel of the forties constructs a decidedly Muslim Indian world. In Purdah and Polygamy she does not address the issues of nationalism that so troubled the mainstream women's movement in colonial India. The stories of Swarnakumari Devi's compromised revolt and Hussain's beautifully controlled fury deserve separate examinations, which take into account these writers' distinct political, cultural, and religious contexts and allegiances.

\section{WORKS CITED}

Basu, Aparna. "The Role of Women in the Indian Struggle for Freedom." Indian Women: From Purdah to Modernity. 1976. Ed. B.R. Nanda. New Delhi: Radiant 1990. 16-40.

Bahadurji, G. J. "Women and Political Struggle." Our Cause: A Symposium by Indian Women. Ed. Shyam Kumari Nehru. Allahabad: Kitabistan, [1936]. 321-338.

Chakravarti, Uma. "Whatever Happened to the Vedic Dasi?: Orientalism, Nationalism, and a Script for the Past." Recasting Women: Essays in Colonial History. Eds. Kumkum Sangari and Sudesh Vaid. New Delhi: Kali for Women, 1989. 27-87.

Chatterjee, Partha. Nationalist Thought and the Colonial Worid: A Derivative Discourse? London and Delhi: Zed Books and Oxford UP, 1986.

Chattopadhyaya, Kamaladevi. "The Status of Women in India." Women in Modern India: Fifteen Papers by Indian Women Writers. 1929. Eds. Evelyn C. Gedge and Mithan Choksi. Westport: Hyperion 1976. 1-13. The Awakening of Indian Women. Madras: Everyman, 1939

Gandhi, Mohandas K. The Collected Works of Mahatma Gandhi. Vol. 30. New Delhi: The Publications Division, 1968.

M. K. Gandhi: Select Speeches. Ed. B. K. Ahluwalia. New Delhi: Sagar, 1969.

M. K. Gandhi: Select Writings. Ed. B. K. Ahluwalia. New Delhi: Sagar, 1970.

Ghosal, Swarnakumari Devi (or Srimati Svarna Kumari Devi). The Fatal Garland. 1915. New York: Macmillan, 1918. Short Stories. Madras: Ganesh, 1919. An Unfinished Song. 1913. New York: Macmillan, 1914.

Ghose, Sankar. Congress Presidential Speeches: (A Selection). Calcutta: Haradhan Chakrabarty, 1972. 
Hasan, Sakinatul Fatima Wazir. "Indian Muslim Women-A Perspective." Our Cause: A Symposium of Indian Women. Ed. Shyam Kumari Nehru. Allahabad: Kitabistan, [1936.] 22-26

Hussain, lqbalunnisa. Purdah and Polygamy: Life in an Indian Muslim Household. Bangalore: Hosali, 1944.

Liddle, Joanna and Rama Joshi. Daughters of Independence: Gender. Caste and Class in India. 1986. New Brunswick: Rutgers UP, 1989

Mehta, Hansa. Indian Woman. Delhi and Baroda: Butala, 1981.

Menon, Lakshmi N. "Women and the National Movement." Indian Woman. Ed. Devaki Jain. New Delhi: Ministry of Information and Broadcasting, Government of India, 1976. 21-28.

Mukherjee, Meenakshi. The Twice Born Fiction: Themes and Techniques of the Indian Novel in English. New Delhi: Heinemann, 1971.

Narayan, R. K. The Dark Room. 1938. Chicago: The U of Chicago P, 1981.

Nehru, Shyam Kumari. Introduction. Our Cause: A Symposium by Indian Women. Allahabad: Kitabistan, [1936.]

Tarafdar, Radhika Lal. Womanhood in Hindu Society Ancient and Modern. Dacca: published by author, 1936.

Walsh, William. R. K. Naravan: A Critical Appreciation. London: Heinemann, 1982. 